The $5^{\text {th }}$ International Conference on Family Business and Entrepreneurship

\title{
FISCAL MANAGEMENT PRACTICES AND SCHOOL PERFORMANCE OF TESDA TECHNOLOGY INSTITUTIONS (TTIS) IN PANAY ISLAND
}

\author{
Jonna Jay F. Gervero', Evangeline B. Ybanez ${ }^{2}$ \\ ${ }^{1,2}$ Faculty of Business, Colegio de la Purisima Concepcion, Corresponding author: sgs@purisima.edu.ph
}

\begin{abstract}
Finance is the backbone of the educational system which challenges administrators' leadership and capabilities, especially educational programs and projects involving greater responsibilities and liabilities. The study determined the level of fiscal management practices of TESDA Technology Institutions (TTIs) in financial literacy, financial planning, and transparency and degree of school performance and their relationship with faculty and staff. Descriptive-correlational and mixed methods were used with quantitative and qualitative data. A survey questionnaire and in-depth interview were used in data gathering. The respondents were two hundred eleven (211) faculty and staff of TESDA Technology Institutions in Panay Island. Frequency count, percentage and mean were used while t-test for independent samples, and Pearson $r$ for relationship. Results on the level of fiscal management practices when taken as a whole and in terms of financial literacy, financial planning, and transparency was found "satisfactory", with financial literacy having the highest mean. The degree of school performance in terms of quality service and student service efficiency was also "satisfactory", with quality service having the highest mean. Significant differences existed when respondents were grouped according to sex and educational attainment. However, no significant differences occurred between the level of fiscal management practices and variables such as position, age, civil status, and length of service. No significant differences were found on the degree of school performance of TESDA Technology Institutions in terms of quality service and students service efficiency as to sex, position, age, civil status, and length of service, except on educational attainment. Significant relationships were found on the level of fiscal management practices and the degree of school performance of TESDA Technology Institutions.
\end{abstract}

Keywords: Fiscal management, Financial literacy, Planning transparency

\section{Introduction}

Many school leaders struggle with grasping the scope of their responsibilities and liabilities when it comes to accounting and finance. School leaders take on a colossal amount of responsibilities. Understanding the various duties required for financial management may seem overwhelming. Accounting and financial reporting is at the crux of a school's financial and academic success. They are the key leaders in the educational system who resoundingly carry out the school vision and mission. It is important that aspiring school leaders have a background and knowledge on the financial aspect of the organization. Ironically, they lack the necessary knowledge, training and skills.

Financial management is among their functions which is central to the success of the organization (Pandey, 2010). Careless financial management practices are the main cause of failure for business enterprises, associations and organizations in almost all countries in the world (Kawame, 2010). Currently, Technology Institutions undertake direct training activities for Technical Education and Skills Development Authority 
(TESDA). They serve as venues to test new training schemes and as laboratories for new technology. It is mandated to provide quality technical education and skills development to the people in the Philippines and to create opportunities for people to be responsible and productive. (Greenspan, 2015). School head's role has changed significantly in the last few decades and management and administrative responsibilities have multiplied with the rise of technology, new legislation requirements, and the pressures of the economy. Understanding the various duties required for financial management may seem overwhelming.

In India, all regulatory bodies have been working towards boosting financial literacy of school managers, namely, RBI, NCFE, NISM, IRDA, PFRDA, SEBI etc. Banks and AMCs. Awareness programs across India finance managers on financial literacy education at school level. This enables future generations to manage their finances very well and avert problems while investing their money. In the Philippines, head of institution is the Fiscal Manager that needs to perform the following functions: prepare a financial management plan; develop a school budget based on guidelines; generates and mobilizes financial resources; manages school resources; manages a process for registration, maintenance, and replacement of school assets and dispositions of non-reusable properties; organizes a procurement committee; ensures that the official procurement process is followed; utilizes funds for approved school programs and projects; monitors utilization, recording and reporting of funds; accounts for school funds; and prepares, submits, communicates financial reports to higher education authorities and other education partners. The findings would serve as a guide to researchers and other aspiring school leaders on becoming effective and efficient school administrators. Results on the evaluation of their fiscal management practices in relation to school performance of TESDA Technology may serve as basis for planning, policy formulation and enhancement of their economic management capabilities.

\section{Statement of the Problem}

The study aimed to determine the level of fiscal management practices in relation to school performance of TESDA Technology Institutions (TTIs) in Panay Island for the school year 2020-2021. Specifically, this study aimed to answer the following questions:

1. What is the level of fiscal management practices of TTIs in Panay Island as a whole and in terms of financial literacy, financial planning and transparency?

2. What is the degree of school performance of TTIs in Panay Island as a whole and in terms of quality service and student service efficiency?

3. Is there a significant difference in the level of fiscal management practices of TTIs in Panay Island when respondents are grouped according to sex, age, civil status, length of service, educational attainment and position?

4. Is there a significant difference in the degree of school performance of TTIs in Panay Island when respondents are grouped according to sex, age, civil status, length of service, educational attainment and position?

5. Is there a significant relationship between the level of fiscal management practices and the degree of school performance of TTIs in Panay Island?

\section{Hypotheses of the Study}

1. There are no significant differences in the level of fiscal management practices of in Panay Island in terms of financial literacy, financial planning, and literacy when respondents are grouped according to the sex, age, civil status, length of service, educational attainment, and position.

2. There is no significant difference in the degree of school performance of TTIs in Panay Island in terms of quality service, and student service efficiency when respondents are grouped according to the sex, age, civil status, length of service, educational attainment, and position.

3. There is no significant relationship between the level of fiscal management practices and the degree of school performance.

\section{Theoretical Framework}

This study was anchored on the Financial Management Theory, Brigham (1971). A business has to makes financial decisions all the time, such as investment decisions, requirements for labor or manpower, raw material purchases and stocks, advertisements \& marketing expenses. A fiscal manager may have personal goals that compete with the government goals of maximization of school's assets. Fiscal manager is expected to have good financial abilities and capabilities to enhance the trust and confidence of workers under his/her leadership. The result of good financial management is quality service and efficient services. The biggest benefit of using financial management theory is that it offers diverse plans of action and tools, 
which business owners can use to increase profit, by following aggressive strategies in investment \& cost control. The primary agency relationships in school are those among owners, stockholders, fiscal managers, teachers, students and parents and other stakeholders.

Financial management theory assists managers and directors by providing tools for operation. Fiscal managers should not make any decisions that would run contrary to the best interest of the school. There are techniques to deal with a single financial issue and sometimes such techniques become very difficult to follow especially when once implemented they bring about change within the business system and structure.

Likewise, the agency theory postulates that in order to avoid conflicts, fiscal managers should have special skills in school governance such as financial literacy, financial transparency, and quality service. Agency Theory suggests that to maximize the strength of the organizations, fiscal managers should have knowledge in financial literacy and efficiency of the school organization. These relationships are not necessarily harmonious; indeed, agency theory is concerned with so-called agency fiscal management, human resource, material resource and other interests between fiscal managers and teachers.

\section{Conceptual Framework}

The study considered three components for fiscal management practices, namely: 1) financial literacy; 2) financial planning; 3) transparency of school administrators and school performance in terms of quality service and student service efficiency. Selected variables such as sex, age, civil status, length of service, educational attainment, and position were assumed to affect perception about their administrators' fiscal management practices and school performance while the level of fiscal management practices is affected by the degree of school performance such as quality service and student service efficiency.

This study assumed the significant relationship of the level of fiscal management practices and the degree of school performance among TTIs in Panay Island. The dependent variables, level of fiscal management practices, were categorized into financial literacy, financial planning and transparency. The sociodemographic profile of the employees can influence their views and insights of their administrator's fiscal management practices and degree of school performance. Included also in the dependent variables is the degree of school performance in terms of quality service and student service efficiency.

Independent variable

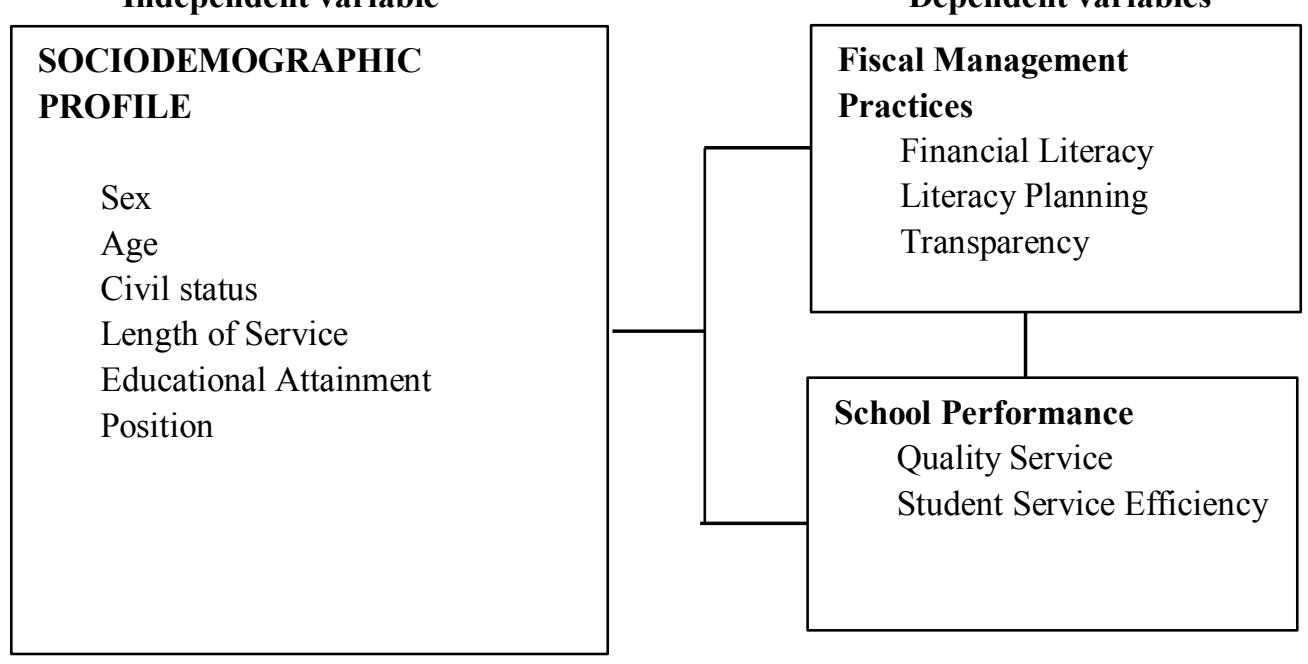

Figure 1: The schematic diagram showing the framework of the study.

\section{Literature Review}

Financial management generally refers to a set of behaviours in the areas of cash management, credit management, financial planning, investments, insurance, and retirement and estate planning (Godwin, 2014; The findings of research studies generally reveal that school managers who use more of the financial management practices recommended by experts report a lower level of financial hardship or stress (Joo \& Grable, 2014; Webley, \& Walker, 2015) and a higher degree of satisfaction with their financial status (Godwin, 2011) than school managers who employ few of the recommended strategies. Research literature suggests that there is a strong negative relationship between financial difficulties and financial satisfaction 
among our school managers (Grable, 20014; Moreover, a substantial body of research has examined the determinants of financial hardship and dissatisfaction among teachers, due to failed leadership of our school heads in terms of the fiscal aspect of the school. Although help-seeking behaviour or attitudes toward seeking help on financial issues has received little empirical attention, there is some evidence to suggest that most school managers prefer to seek help on financial matters from non-professionals rather than financial professionals and organizations (Chen \& Volpe, 2012). School leaders choosing to seek help on financial matters must choose between assistance options including financial planners, financial counsellors, financial assistance organizations, attorneys, and non-professionals (such as friends, colleagues, and family) (Grable \& Joo, 2012). However, the study of university leaders, Leach, Turner, Bruin, and Lawrence (2010) found that there was a significant negative relationship between financial management practices and financial stress for both males and females school managers although this relationship was significantly stronger for males. In a study examining the decision to either seek or not seek personal finance help with either professionals or non-professionals, Grable and Joo, (2012) found that those who sought help were school heads who exhibited worse financial behaviours and more financial stressors. There was evidence to suggest that, although they had a relatively high disposable income, this generation of school managers displayed low rates of financial literacy (i.e., knowledge and skills related to money management) (Avard, Manton, 2012). This study found that, in a sample of undergraduate university students in Singapore, schools that had experienced financial hardship were more likely those schools managed by school leaders who had none or little knowledge about fiscal policies. Lea et al., 2015) among school managers Lim and Teo (2017) provide some evidence that money attitudes are also related to financial hardship among different schools due to fiscal failure of school managers.

Financial problems of a school were found to be negatively related to financial literacy of a school manager, whereby those who were experiencing problems related to a lack of resources for essential expenses reported lower levels of financial satisfaction among their employees. While these studies provide valuable information regarding the financial management practices and money attitudes in young school managers, most studies focused on university managers. The findings of their study suggested that school managers seeking help from professional sources tended to be those who had a higher level of financial risk tolerance, owned their own home, indicated a high level of financial satisfaction, exhibited better financial behaviours, and were older. Better financial management practices were related to lower levels of financial problems and higher levels of financial satisfaction among employees. Relatively little is known about the financial management practices and money attitudes of school managers in schools. Therefore this study is designed to examine the financial management practices and school performance of Technical Educational School Development Authority (TESDA) in Panay Island. For example, Joo and Grable (2012) found that the second most dominant determinant of financial satisfaction, after financial management practices, was an individual's financial literacy level. It was also determined that financial management practices significantly predicted financial problems and satisfaction among employees. In fact, financial management practices were the most influential determinant of financial problems especially in a certain institution.

Fiscal management programs can help young male school managers to overcome their financial problems and dissatisfaction by normalizing unhelpful money attitudes, increasing their awareness of the assumptions underlying their beliefs, evaluating their validity on a evidential basis, and modifying and replacing these beliefs with more appropriate beliefs (Beck, 2015). Specifically, the results suggest that financial education courses or financial counselling programs for male school managers should include education in basic personal financial management, such as cash management, credit use management, budgeting, financial planning, general money management, and consumer decision making (Joo \& Grable, 2012). Taken together, these findings imply that these money attitudes on being transparent, in addition to financial management practices, should be the target of financial education initiatives for young male school managers. The interpretation of these findings posited by Lim and Teo (2017) are that school managers who had experienced financial problems tended to view money as a form of evaluation and experience more anxiety because they had experienced being looked down upon when they needed money before and because they had undergone the emotional psychological distress associated with financial deprivation during their childhood years.

\section{Research Methods}

The descriptive-correlation method of research was utilized to determine the level of fiscal management practices in relation to the degree of school performance of TTIs in Panay Island for school year 20202021. The socio-demographic profile of the respondents included sex, age, civil status, length of service, 
educational attainment, and position, whereas the dependent variables were the level of fiscal management practices in terms of financial literacy, financial planning, and transparency, and the degree of school performance in terms of quality service that focused on the operation of each institution and student service efficiency that focused on the services of the institutions to the students. The participants were two hundred eleven (211) faculty and staff from 243 total population randomly selected in the four (4) TTIs in Panay Island - Dumalag Vocational-Technical School, Leon Ganzon Polytechnic College, New Lucena Polytechnic College and Passi Trade School. Four (4) administrators, twenty-four (24) faculty and staff were purposely selected to participate in the in-depth interview to add support to the quantitative data of the study. A researcher-made questionnaire with rating scale and in-depth interview using the transcendental realism approach of data analysis (Huberman \& Miles, 1994) was used. This method provided assistance in extracting, organizing and analysing the narrative data set. Analysis of data was done using descriptive statistics: frequency, percentage, mean and for the inferential statistics: t-test, Analysis of Variance (ANOVA) and Pearson r. Significance level was set at 0.05 alpha level. The In-depth Interview was administered to the one (1) administrator, three (3) faculty and three (3) staff of every TTIs in Panay Island. The data gathered were collected and tabulated in a matrix. The data was computer-processed.

\section{Results and Discussion}

\section{Level of Fiscal Management Practices}

The level of fiscal management practices of TTIs in Panay Island had the overall grand mean as of 3.22 shown in Table 1. Results showed satisfactory level of fiscal management practices of the school administrators. The grand mean 3.42 for financial literacy meant school administrators have a very satisfactory level of fiscal management practices. The lowest grand mean of 2.99 , for transparency indicated satisfactory level of fiscal management of fiscal managers was not consistently manifested.

Table 1. Level of fiscal management practices in terms of financial literacy, financial planning, and transparency.

\begin{tabular}{|c|c|c|}
\hline Indicators & Mean & Verbal Interpretation \\
\hline Financial Literacy & 3.42 & Very Satisfactory \\
\hline Financial Planning & 3.25 & Satisfactory \\
\hline Transparency & 2.99 & Satisfactory \\
\hline Grand Mean & 3.22 & Satisfactory \\
\hline
\end{tabular}

Results correlated (Henry, and Johnson, 2018) financial management field is becoming increasingly concerned with the financial practices of different schools today.

Financial literacy. Shown in table 2 is the level of fiscal management practices in terms of financial literacy. Ten statements had means from 2.37 to 4.10 . The highest mean of 4.10, was "very satisfactory", and knows the process of registration, maintenance, and replacement of school assets and 2.37 rated fair for not facilitating the liquidation reports. Results reveal the level of fiscal management practices of fiscal managers in terms of financial literacy was "very satisfactory". It showed the condition of financial literacy of fiscal managers in every TTIs in Panay Island and was exhibited now and then.

Table 2. Level of fiscal management practices in terms of financial literacy.

\begin{tabular}{lcc}
\multicolumn{1}{c}{ Statements } & Mean & $\begin{array}{c}\text { Verbal } \\
\text { Interpretation }\end{array}$ \\
\hline $\begin{array}{l}\text { 1. Knows the ins and outs of financial management. } \\
\text { 2. Does not understand the details of the school budget. }\end{array}$ & 4.08 & Very Satisfactory \\
3. Knows basic accounting and auditing procedures. \\
$\begin{array}{l}\text { 4. Is unaware about the financial software being used for } \\
\text { management. }\end{array}$ & 3.51 & Fair \\
5. Is actively involved in budget preparation. & & Very Satisfactory \\
6. Generates and mobilizes financial resources. & 3.80 & Very Satisfactory \\
$\begin{array}{l}\text { 7. Knows how to execute the financial management plan. } \\
\text { 8. Manages school resources not in accordance with TESDA } \\
\quad \text { Policies, accounting, auditing, and other pertinent } \\
\text { guidelines. }\end{array}$ & 3.96 & Very Satisfactory \\
9. Knows the process of registration, maintenance, and \\
$\quad$ replacement of school assets.
\end{tabular}


To support the results of the quantitative data indicated school administrators in terms of financial literacy that transpired insights from the participants during the virtual in-depth interview was provided through a tabular presentation. This result is supported by the study conducted by (Hilgert and Hogarth, 2012). They noted that financial literacy played a significant role for the success in running a school. They further noted that a school leader should know the ins and outs of financial management.

Table 3. Qualitative data on financial literacy of school administrators.

\begin{tabular}{|c|c|c|}
\hline Key Questions & Themes $/ *$ Code Abbreviation Sub-Theme & $\begin{array}{c}\text { Frequency } \\
\mathrm{N}=4\end{array}$ \\
\hline $\begin{array}{l}\text { How do you manage school } \\
\text { financial resources in terms of } \\
\text { financial literacy? }\end{array}$ & $\begin{array}{l}\text { - Manage school resources properly } \\
\text { - Monitor financial transaction of school }\end{array}$ & $\begin{array}{l}4(100 \%) \\
4(100 \%)\end{array}$ \\
\hline
\end{tabular}

Table 4. Qualitative data on financial literacy of faculty and staff.

\begin{tabular}{ccc}
\hline Key Questions & $\begin{array}{c}\text { Themes/*Code Abbreviation Sub- } \\
\text { Theme }\end{array}$ & $\begin{array}{c}\text { Frequency } \\
\mathrm{N}=24\end{array}$ \\
\hline $\begin{array}{c}\text { What can you say about the fiscal } \\
\text { management practices of your school } \\
\text { administrator in terms of financial } \\
\text { literacy? }\end{array}$ & $\begin{array}{c}\text { W/TESDA policies and guidelines } \\
\text { Wanage school funds in accordance }\end{array}$ & $15(16.50 \%)$ \\
& - Financially literate & $15(16.50 \%)$ \\
\end{tabular}

Financial planning. The level of fiscal management practices of TTIs in Panay Island in terms of financial planning was presented in Table 5. These school administrators had a "satisfactory" level of fiscal management practices in terms of financial planning supported by 2.25 to 4.22 means. The administrators were particularly prioritizing financial allocation according to the needs of the school and ensuring that budgets reflect the agreed institutional goals and objectives, hence the outstanding rating. While the 2.25 mean signified fair for disapproves and/or cuts budget unreasonably. The results revealed that financial planning of fiscal managers was "satisfactory". As (Joo and Garman, 2018; Peter et al, 2017) posited fiscal managers need more training in financial planning and keep close monitoring of all financial transactions delegated to the staff.

Table 5. Level of fiscal management practices in terms of financial planning.

\begin{tabular}{|c|c|c|}
\hline Statements & Mean & $\begin{array}{c}\text { Verbal } \\
\text { Interpretation }\end{array}$ \\
\hline $\begin{array}{l}\text { 1. Does not join with the management staff and heads of } \\
\text { departments/units in planning for the school budget. }\end{array}$ & 2.43 & Fair \\
\hline $\begin{array}{l}\text { 2. Prioritizes financial allocation according to the needs of the } \\
\text { school. }\end{array}$ & 4.22 & Outstanding \\
\hline $\begin{array}{l}\text { 3. Lacks knowledge on how to source funds for school } \\
\text { improvement. }\end{array}$ & 2.38 & Fair \\
\hline $\begin{array}{l}\text { 4. Keeps close monitoring of all financial transactions delegated } \\
\text { to the staff. }\end{array}$ & 4.04 & $\begin{array}{c}\text { Very } \\
\text { Satisfactory }\end{array}$ \\
\hline $\begin{array}{l}\text { 5. Ensures that budgets reflect the agreed institutional goals and } \\
\text { objectives. }\end{array}$ & 4.22 & Outstanding \\
\hline 6. Works within the constraints of the school budget. & 4.06 & $\begin{array}{l}\text { Very } \\
\text { Satisfactory }\end{array}$ \\
\hline 7. Sees accurate financial information about the school. & 4.09 & $\begin{array}{l}\text { Very } \\
\text { Satisfactory }\end{array}$ \\
\hline $\begin{array}{l}\text { 8. Hides the real status of the financial position of the school. } \\
\text { 9. Does not involve all stakeholders in the strategic planning for }\end{array}$ & 2.42 & Fair \\
\hline future direction of the school. & 2.37 & Fair \\
\hline 10. Disapprove and/or cut the budget unreasonably. & 2.25 & Fair \\
\hline Grand Mean & 3.25 & Satisfactory \\
\hline
\end{tabular}

To substantiate the quantitative data as to the level of fiscal management practices in terms of financial planning, insights gathered from the in-depth interview participants provided and shown in tabular form. The respondents on school administrator shared that they tap industry partners to support the institution's 
program and create a procurement committee to help in financial planning. Insights of school administrators have the same on faculty and staff. Those insights are organized using themes. For clarity of presentation and discussion, table 6 and table 7 are provided.

Table 6. Qualitative data on financial planning of school administrators.

\begin{tabular}{lcc}
\hline \multicolumn{1}{c}{ Key Questions } & Themes/*Code Abbreviation Sub-Theme & $\begin{array}{c}\text { Frequency } \\
\mathrm{N}=24\end{array}$ \\
\hline $\begin{array}{l}\text { How do you manage school } \\
\text { financial resources in terms } \\
\text { of financial planning? }\end{array}$ & - Very good tapping industry partners & $3(75 \%)$ \\
\hline
\end{tabular}

Table 7. Qualitative data on financial planning of faculty and staff

\begin{tabular}{lll}
\hline \multicolumn{1}{c}{ Key Questions } & Themes/*Code Abbreviation Sub-Theme & $\begin{array}{c}\text { Frequency } \\
\mathrm{N}=24\end{array}$ \\
\hline $\begin{array}{l}\text { What can you say about the fiscal } \\
\text { management practices of your }\end{array}$ & - Create a committee on procurement & $10(41.66 \%)$ \\
$\begin{array}{l}\text { school administrator in terms of } \\
\text { financial planning? }\end{array}$ & $\begin{array}{l}\text { Does not involve faculty and staff in } \\
\text { budget planning }\end{array}$ & $10(41.66 \%)$ \\
\hline
\end{tabular}

Further, Balasa (2011) supported that school leaders should provide guidance to the employees, it is easy to believe that others think the way they do, and understand the bigger picture as they do. Thus, it is vital that they walk people through the steps of what they are planning, and provide guidance and mentorship where it is needed.

Transparency. The level of transparency in fiscal management practices of TTIs in Panay Island is presented in Table. The level of transparency ranged from 2.39 to 4.07 described satisfactory. The findings revealed school managers prepare financial reports and submit them to higher authorities. Transparency and full disclosure of financial practices is a part of the organization's Code of Ethics. It was claimed school administrator is good fiscal manager and knows how to handle school funds. As per (IFAC, 2012) all financial transactions of the school must reported and posted on the bulletin board in conspicuous places. This ensure trust and confidence among the teachers and to eradicate any doubt of corruption. The ways school administrators lead the organization depend on the leadership styles, concepts of honesty, trustworthiness and integrity as core values for effective schools and successful leaders (Malone, 2013).

Table 8. Level of Fiscal Management Practices in terms of Transparency.

\begin{tabular}{|c|c|c|}
\hline Statements & Mean & $\begin{array}{c}\text { Verbal } \\
\text { Interpretation }\end{array}$ \\
\hline 1. Prepares a financial management report on time. & 3.99 & Very Satisfactory \\
\hline $\begin{array}{l}\text { 2. Does not post accurate updated financial information of the } \\
\text { school MOOE in the bulletin board. }\end{array}$ & 2.58 & Fair \\
\hline 3. Utilizes funds for approved school programs and projects & & \\
\hline as reflected in the school improvement plan. & 4.07 & Very Satisfactory \\
\hline 4. Gives no reason in implementing his cost saving strategies. & 2.54 & Fair \\
\hline $\begin{array}{l}\text { 5. Fails to present regularly the financial status of the school to } \\
\text { faculty and staff. }\end{array}$ & 2.48 & Fair \\
\hline 6. Organizes a procurement committee inconsistently. & 2.96 & Satisfactory \\
\hline 7. Fails to carry out periodic audit of school budgets. & 2.48 & Fair \\
\hline $\begin{array}{l}\text { 8. Prepares financial reports and submits the same to higher } \\
\text { authorities. }\end{array}$ & 2.99 & Very Satisfactory \\
\hline $\begin{array}{l}\text { 9. Does not create a committee that supervises any school } \\
\text { project that involves big budget allocation. }\end{array}$ & 2.42 & Fair \\
\hline $\begin{array}{l}\text { 10. Does not ask for a canvass sheet every time there is a } \\
\text { purchase request. }\end{array}$ & 2.39 & Fair \\
\hline Grand Mean & 2.99 & Satisfactory \\
\hline
\end{tabular}

To support the quantitative data, the ideas and opinions shared by the in-depth interview participants are given and it is presented in tabular form to further support the result. The result has three (3) themes for 
school administrators and four (4) themes for faculty and staff and it shows that some schools do not practice transparency on school budgets. For clarity of presentation and discussion, table 9 and table 10 is presented.

Table 9. Qualitative data on transparency of school administrators.

\begin{tabular}{llc}
\hline \multicolumn{1}{c}{ Key Questions } & Themes/*Code Abbreviation Sub-Theme & $\begin{array}{c}\text { Frequency } \\
\mathrm{N}=4\end{array}$ \\
\hline How do you manage & Does not post financial report & $3(75 \%)$ \\
school financial & Inform faculty and staff about school financial & $3(75 \%)$ \\
resources in terms of & status & $3(75 \%)$ \\
transparency? & Value integrity and transparency & \\
\hline
\end{tabular}

Table 10. Qualitative data on transparency of faculty and staff.

\begin{tabular}{|c|c|c|}
\hline Key Questions & Themes $/ *$ Code Abbreviation Sub-Theme & $\begin{array}{l}\text { Frequency } \\
\mathrm{N}=24\end{array}$ \\
\hline \multirow{3}{*}{$\begin{array}{l}\text { What can you say about the } \\
\text { fiscal management practices of } \\
\text { your school administrator in } \\
\text { terms of transparency? }\end{array}$} & - Post financial report & $2(8.34 \%)$ \\
\hline & $\begin{array}{l}\text { - Assign financial committee from faculty and } \\
\text { staff }\end{array}$ & $3(12.51 \%)$ \\
\hline & - Does not post financial status of the school & $6(25.02 \%)$ \\
\hline
\end{tabular}

Degree of school performance

The degree of school performance of TTIs in Panay Island in table 3 had an overall grand mean of 3.10 as satisfactory. Quality service component had 3.12 mean and the student service efficiency component had 3.07 mean rated satisfactory respectively. Results were consistent with the standard set by the Commission on Higher Education. It showed school performance of fiscal managers when taken as a whole was "satisfactory". Fiscal managers improved the quality service and student's service efficiency of the schools. Quality service can only be done if sound fiscal policy is adopted. The indicators, namely quality service and student service efficiency, showed that the condition of the degree of performance of TTIs in Panay Island was "good". As Starcher (2012) posited to improve a school must upgrade its system, set clear goals and objectives. It is therefore important that the performance of a school is appraised. They contend it must improve its services to its clientele by upgrading its systems, services, and technology. The study of Baron and Arnstrong (2017) affirms the result of this study.

Table 11. Degree of school performance.

\begin{tabular}{llll}
\hline \multicolumn{1}{c}{ Indicators } & Mean & Verbal Interpretation \\
\hline Quality Service & & 3.12 & Satisfactory \\
Student Service Efficiency & 3.07 & Satisfactory \\
\multicolumn{1}{c}{ Grand Mean } & 3.10 & Satisfactory \\
\hline
\end{tabular}

Quality service. Shown in Table 3a is the degree of quality service of TTIs in Panay Island. The grand mean was 3.12 implies satisfactory quality service while the 2.14 , "fair" referred to lack of skilful and knowledgeable faculty and staff. The highest mean of 4.24, "outstanding", denoted clear goals and objectives that promote a continuous improvement plan system. The result tells that every school creates a quality management committee to ensure the delivery and programs of school are based on the standards. This means TTIs are doing their best to subscribe to the standards set forth by the Commission on Higher Education. It is a must for all TESDA Accredited schools to upgrade their system and standard or else they will face sanction or closure. Fiscal managers devoted time to improve the quality service of the school by reviewing the curriculum, systems, programs, and the services of the school through providing the trainers and trainees with state of the art technology. 
Table 12. Degree of school performance in terms of quality service.

\begin{tabular}{|c|c|c|}
\hline Statements & Mean & $\begin{array}{c}\text { Verbal } \\
\text { Interpretation }\end{array}$ \\
\hline $\begin{array}{l}\text { 1. Clear goals and objectives that promote a continuous } \\
\text { improvement plan system. }\end{array}$ & 4.24 & Outstanding \\
\hline $\begin{array}{l}\text { 2. No system of assessing performance and functions of school } \\
\text { personnel. }\end{array}$ & 2.16 & Fair \\
\hline $\begin{array}{l}\text { 3. A quality management system in implementing the agency } \\
\text { standards for TTIs. }\end{array}$ & 4.13 & Very Satisfactory \\
\hline 4. Lacks skillful and knowledgeable faculty and staff. & 2.14 & Fair \\
\hline $\begin{array}{l}\text { 5. Conducted research and curriculum review for the } \\
\text { improvement and innovation of our school programs. }\end{array}$ & 3.78 & Very Satisfactory \\
\hline 6. Poor completion rate vis-a-vis the enrolment. & 2.20 & Fair \\
\hline $\begin{array}{l}\text { 7. Has graduates that underwent mandatory assessment within } \\
5 \text { days (after graduation). }\end{array}$ & 3.65 & Very Satisfactory \\
\hline 8. Very low employment rate of graduates. & 2.48 & Fair \\
\hline $\begin{array}{l}\text { 9. High and increasing certification rate of graduates in all } \\
\text { programs offered. }\end{array}$ & 4.16 & Very Satisfactory \\
\hline $\begin{array}{l}\text { 10. The school has not produced learners or graduates who have } \\
\text { received Skills Competition Awards. } \\
\text { Grand Mean }\end{array}$ & $\begin{array}{l}2.29 \\
3.12\end{array}$ & $\begin{array}{l}\text { Fair } \\
\text { Satisfactory }\end{array}$ \\
\hline
\end{tabular}

For clarity of presentation and discussion, table 13 is presented. The study of Sahito (2016) supports the results who averred that Technological schools must produce graduates or learners that have quality skills based on the need of different companies. Participants (IDIAP-04) contended as follows: Quality service is the school emphasis that is why we create a committee on quality management, when choosing that member. I will always go by position, ability and capability. As Sahito (2016) stated in assessing the performance of the faculty and staff we have Individual Performance Commitment and Review (IPCR) to measure their efficiency, quality and timeliness on their respective designation. To support the results of the quantitative data as to the degree of quality service in school performance, the insights from the participants during the interview support the above findings.

Table 13. Qualitative data on quality service of school administrators.

\begin{tabular}{|c|c|c|}
\hline Key Questions & $\begin{array}{l}\text { Themes } /{ }^{*} \text { Code Abbreviation Sub- } \\
\text { Theme }\end{array}$ & Frequency $\mathrm{N}=4$ \\
\hline \multirow{3}{*}{$\begin{array}{l}\text { How do you assess the } \\
\text { performance of your } \\
\text { institution in terms of } \\
\text { quality service? }\end{array}$} & $\begin{array}{l}\text { - Create quality management } \\
\text { committee }\end{array}$ & $4(100 \%)$ \\
\hline & $\begin{array}{l}\text { - Conduct research and } \\
\text { curriculum reviews }\end{array}$ & $4(100 \%)$ \\
\hline & - Evaluate program registration & $3(75 \%)$ \\
\hline
\end{tabular}

Table 14. Qualitative data on quality service of faculty and staff.

\begin{tabular}{lll}
\hline \multicolumn{1}{c}{ Key Questions } & \multicolumn{1}{c}{ Themes/*Code Abbreviation Sub-Theme } & $\begin{array}{c}\text { Frequency } \\
\text { N=24 }\end{array}$ \\
\hline $\begin{array}{lll}\text { What can you say } \\
\text { about the school } \\
\text { performance of your } \\
\text { institutions in terms of } \\
\text { quality service? }\end{array}$ & $\begin{array}{l}\text { Clear goals and objectives Formulate quality } \\
\text { management committee }\end{array}$ & $\begin{array}{l}\text { Conduct researches and curriculum reviews } \\
\text { Programs accreditation and evaluation }\end{array}$ \\
\hline
\end{tabular}


Student service efficiency. The grand mean of the degree of student service efficiency of TTIs in Panay Island was 3.07. The ten statements of the degree of student service efficiency of TTIs in Panay Island had means which ranged from 2.48 to 3.80 . The highest mean of 3.80 , with a verbal interpretation of "very satisfactory" was on statement, "activities and programs for personality development like gender and development, III-effects of smoking, time management, etc." The lowest mean of 2.48 with a verbal interpretation of "fair" was on statement, "deficiency in active partner companies/institutions in the implementation of on-the-job or job referral related to the program undergone".

Table 15. Degree of school performance in terms of student service efficiency.

\begin{tabular}{|c|c|c|}
\hline Statements & Mean & $\begin{array}{c}\text { Verbal } \\
\text { Interpretation }\end{array}$ \\
\hline A cost-friendly canteen for students. & 2.86 & Satisfactory \\
\hline $\begin{array}{l}\text { 2. Deficiency in active partner companies/institutions in the } \\
\text { implementation of on-the job or job referral related to the program } \\
\text { undergone. }\end{array}$ & 2.48 & Fair \\
\hline $\begin{array}{l}\text { 3. Activities and programs for personality development like Gender and } \\
\text { Development, Ill-Effects of Smoking, Time Management, tc. }\end{array}$ & 3.80 & $\begin{array}{l}\text { Very } \\
\text { Satisfactory }\end{array}$ \\
\hline No drinking fountain for students. & 2.77 & Satisfactory \\
\hline 5. A functional library with sufficient chairs and tables for students to use. & 3.67 & $\begin{array}{l}\text { Very } \\
\text { satisfactory }\end{array}$ \\
\hline No facilities that are PWD-friendly. & 2.60 & Fair \\
\hline 7. A health and wellness program for students. & 3.45 & $\begin{array}{l}\text { Very } \\
\text { Satisfactory }\end{array}$ \\
\hline $\begin{array}{l}\text { 8. No strict implementation of the number of enrolled learners within the } \\
\text { absorptive capacity of the program relative to Training Regulations. }\end{array}$ & 2.72 & Satisfactory \\
\hline 9. Clean and well-maintained school building and campus grounds. & 3.75 & $\begin{array}{l}\text { Very } \\
\text { Satisfactory }\end{array}$ \\
\hline $\begin{array}{l}\text { 10. No feedback mechanism where complaints of students can be formally } \\
\text { manifested. }\end{array}$ & 2.63 & Satisfactory \\
\hline Grand Mean & 3.07 & Satisfactory \\
\hline
\end{tabular}

To support the quantitative data, the ideas and opinions shared by the in-depth interview participant are given and it is presented in tabular form to further substantiate the result as shown in table 16 and 17. Students now are very active on the internet that is why they should be provided with the new trends of learning the use of technology. Results of both quantitative and qualitative data imply that institutional facilities and support services should continue to be provided to facilitate effective teaching and delivery of knowledge as it improves academic performance.

Table 16. Qualitative data on student service efficiency of school administrators.

\begin{tabular}{llc}
\hline \multicolumn{1}{c}{ Key Questions } & Themes $/ *$ Code Abbreviation Sub-Theme & $\begin{array}{c}\text { Frequency } \\
\mathrm{N}=4\end{array}$ \\
\hline & - Survey for feedback mechanism & $3(75 \%)$ \\
How do you assess the performance of & - & Equipped of facilities, materials and \\
your institution in terms of student & $\quad$ equipment for academic needs & $3(75 \%)$ \\
service efficiency? & - Lack of library facilities & $3(75 \%)$ \\
\hline
\end{tabular}

Table 17. Qualitative data on student service efficiency of faculty and staff.

\begin{tabular}{llc}
\hline \multicolumn{1}{c}{ Key Questions } & \multicolumn{1}{c}{ Themes/*Code Abbreviation Sub-Theme } & $\begin{array}{r}\text { Frequency } \\
\text { N=24 }\end{array}$ \\
\hline & - Programs for GAD, PWD, etc. & $15(62.50 \%)$ \\
& - Facilities for students needs & $17(70.83 \%)$ \\
What can you say about the school & - Feedback mechanism & $16(66.66 \%)$ \\
performance of your institutions in terms & & $16(66.66 \%)$ \\
of student service efficiency? & - Available students support services & $16(66.66 \%)$ \\
& - Provide quality training & \\
\hline
\end{tabular}


Differences in the Level of Fiscal Management Practices when Respondents were grouped according to the Selected Profiles

To aid the presentation, analysis, and interpretation of data on the level of fiscal management practices, the frequency and percentage distribution of the socio-demographic profile of the faculty and staff in terms of sex, age, civil status, length of service, educational attainment and position were employed and presented in Table 4. Results showed the respondents were mostly female constituting 60.66, above 40 years old, $152(72.04 \%)$ were married and with 1-10 years length of service, $156(73.93 \%)$ with baccalaureate degree and $154(72.99 \%)$ were faculty.

Table 18. Socio-demographic profile of the respondents.

\begin{tabular}{lcc}
\hline \multicolumn{1}{c}{ Profile } & Frequency & Percent \\
\hline Sex & 83 & 39.34 \\
Male & 128 & 60.66 \\
$\quad$ Female & & \\
Age & 43 & 20.38 \\
20 to 30 years & 52 & 24.64 \\
31 to 40 years old & 116 & 54.98 \\
$\quad$ Above 40 years old & & \\
Civil Status & 50 & 23.70 \\
$\quad$ Single & 152 & 72.04 \\
Married & 9 & 4.26 \\
Widow/er & & \\
Length of Service & 88 & 41.71 \\
1 to 10 years & 47 & 22.27 \\
11 to 20 years & 76 & 36.02 \\
$\quad$ Above 20 years & & \\
Educational Attainment & 156 & 73.93 \\
Baccalaureate Degree & 35 & 16.59 \\
Master's Degree & 13 & 6.16 \\
$\quad$ Doctorate Degree & 7 & 3.32 \\
Vocational/2year course & & 72.99 \\
Position & 57 & 27.01 \\
$\quad$ Faculty & 156 & \\
Admin/Staff & &
\end{tabular}

In table 19 data revealed age, civil status, length of service, and position in terms of level fiscal management practices displayed insignificant differences while sex and educational attainment displayed significant difference. The six socio-demographic profiles have F-value higher than .05 alpha affected by acceptance of the null hypothesis. It implied the level of fiscal management practices of managers did not differ. As to sex and educational attainment the null hypothesis was rejected since the F-value exceeded the 5\% level of significance. It meant variation was prevalent as regards to the level of fiscal management practices of TTIs considering the variables.

Table 19. Differences in the level of fiscal management practices of TTIs in Panay Island when respondents were grouped according to the selected profiles.

\begin{tabular}{lccc}
\hline Component & $\mathrm{t}$ or F- value & Significant Value & Probability \\
\hline Sex & 2.093 & 0.038 & $\mathrm{~s}$ \\
Age & 0.172 & 0.842 & $\mathrm{~ns}$ \\
Civil status & 0.116 & 0.891 & $\mathrm{~ns}$ \\
Length of service & 0.816 & 0.443 & $\mathrm{~ns}$ \\
Educational attainment & 4.466 & 0.005 & $\mathrm{~s}$ \\
Position & 0.801 & 0.424 & $\mathrm{~ns}$ \\
\hline
\end{tabular}

Differences in the Degree of School Performance of TTIs in Panay Island when Respondents were grouped according to Selected Profiles

The difference in the degree of school performance of TTIs in Panay is shown in table 6. Results showed 
significant difference was found when respondents were grouped according to educational attainment; however, no significant differences were found when they were grouped according to their sex, age, civil status, length of service, and position. This meant that respondents vary in their assessment of their school performance according to their educational attainment.

Table 20. Differences in the degree of school performance of TTIs in Panay Island when respondents were grouped according to the selected profiles.

\begin{tabular}{lccc}
\hline \multicolumn{1}{c}{ Component } & t or F-value & Significant Value & Probability \\
\hline Sex & 0.403 & 0.687 & $\mathrm{~ns}$ \\
Age & 0.452 & 0.637 & $\mathrm{~ns}$ \\
Civil status & 0.694 & 0.500 & $\mathrm{~ns}$ \\
Length of service & 0.397 & 0.673 & $\mathrm{~ns}$ \\
Educational attainment & 4.128 & 0.007 & $\mathrm{~s}$ \\
Position & 1.240 & 0.216 & $\mathrm{~ns}$ \\
\hline
\end{tabular}

Relationship between the level of Fiscal Management Practices and the degree of School Performance Result reveals that there was a significant relationship between the level of fiscal management practices and the degree of school performance of TTIs in Panay Island because the Pearson R-value of 0.709 had a significant value of 0.000 , which was less than 0.05 alpha as shown in Table 21. The null hypothesis which states that there is no relationship between the level of fiscal management practices and degree of school performance of TESDA Technology Institutions in Panay Island is rejected. It is manifested that this relationship, articulated the level of fiscal management practices in terms of financial literacy, financial planning and transparency in relation to the degree of school performance in terms of quality service and student service efficiency. The result implies that the assessment of the respondents in the level of fiscal management practices was associated with their assessment in the degree of school performance of TESDA Technology Institutions in Panay Island. The result implies that the level of fiscal management practices is related to the degree of school performance of TTIs in Panay Island.

Table 21. Relationship between the level of fiscal management practices and the degree of school performance of TESDA Technology Institutions in Panay Island.

\begin{tabular}{cccccc}
\hline \multicolumn{1}{c}{ Variable } & $\mathrm{N}$ & Mean & $\begin{array}{c}\text { Pearson r- } \\
\text { value }\end{array}$ & Sig. Value & Probability \\
\hline $\begin{array}{l}\text { Level of Fiscal } \\
\text { Management }\end{array}$ & 211 & 3.2194 & 0.709 & 0.000 & $\mathrm{~s}$ \\
$\quad \begin{array}{l}\text { Practices } \\
\begin{array}{l}\text { Degree of School } \\
\text { Performance }\end{array}\end{array}$ & 211 & 3.0969 & & & \\
\hline
\end{tabular}

\section{Conclusions}

The financial management practices of school administrators of TESDA Technology Institutions in Panay Island are assessed by their faculty and staff as within their expectation, they are financially literate but need to improve on their financial planning and transparency. The school performance of TESDA Technology Institutions in Panay Island performed in accordance with the standard set by TESDA and Commission on Higher Education.

Educational attainment and sex of the respondents tend to cause a variation in their assessment of the financial management practices and school performance of TESDA Technology Institutions in Panay Island. The financial management practices of school administrators and school performance in general of TESDA Technology Institutions in Panay Island are mutually dependent. 


\section{Implications}

Since the need to address the problem on transparency was identified and the administrators will be working with the faculty and staff and as part of the organization, records of activities, utilization of funds and expenditures including performance of faculty and staff be kept accurate and updated and presented to the faculty in a meeting. Even in planning and other activities, involvement of faculty and personnel may be kept in mind.

Linkages of institutions are a common problem thus TESDA may mobilize its forces to strengthen institutional linkages and networking with different partner institutions and stakeholders. TESDA programs and services are made available online or aired regularly as information drives to the people. Likewise, the HR may take note of the problems that may occur relating to alignment of specialization of personnel. To get the best services, time, money and effort, personnel alignment as to specialization will be the best solution.

\section{References}

Beck, AT.(2015). Cognitive Insight on Cooperation and Conflict. DOI:10.1007/978-3-319-10687-8_17

Lim, LW., Teo, WL. (2017). The relational activation of resilience model: How leadership activates resilience in an organizational crisis. https://doi.org/10.1111/1468-5973.12179.

Joo, S.-H., Grable, J. E., Lee, S., \& Kim, M. (2012). Adolescents' financial literacy: The role of financial socialization agents, financial experiences, and money attitudes in shaping financial literacy among South Korean youth. Journal of Adolescence, 35(4), 969-980. https://doi.org/10.1016/j.adolescence.2012.02.002

Brigham, J. C. (1971). Racial stereotypes, attitudes, and evaluations of and behavioral intentions toward Negroes and whites. Sociometry, 34 (3), 360-380. https://doi.org/10.2307/2786204

Pandey I.M. (2010). Financial Management. $10^{\text {th }}$ edition, Vikas Publishing House PVT LTD, Jangpura, New Delhi. 